\title{
Tingkat Kepuasan Pasien terhadap Perawatan Tumpatan Komposit pada Gigi Anterior di RSGM Universitas Sam Ratulangi
}

\author{
Cliviane Kewas \\ Dinar A. Wicaksono \\ Paulina N. Gunawan \\ Program Studi Pendidikan Dokter Gigi Fakultas Kedokteran \\ Universitas Sam Ratulangi Manado \\ Email: clivianekewas@gmail.com
}

\begin{abstract}
Dental caries can be overcome by restoration using composite resin which is widely used as an anterior tooth restoration material due to its aesthetic advantages. Dentists have to fulfil the patient expectation with the best service as possible. Determination of patient satisfaction of the restoration can be evaluated from the patient's assessment. This study was aimed to determine the level of patient satisfaction of composite restoration in the anterior teeth at RSGM Unsrat. This was a descriptive study with a cross-sectional design. Respondents were 30 patients selected by purposive sampling method. The instrument used in this study was a questionnaire with closed questions. The results showed that most respondents' satisfaction level of the restoration was 'very satisfying' (45\%). The satisfaction level of the composite color was 'satisfying enough' (33\%). The satisfaction level of the tooth size was 'satisfying'. Data were processed descriptively then were presented based on distribution in chart forms. In conclusion, the respondents' satisfaction level of the composite restoration in the anterior teeth was most dominant in the 'satisfying' category related to the tooth size after restoration but in the 'satisfying enough' category related to the composite color.
\end{abstract}

Keywords: composite restoration, anterior teeth, patient satisfaction

\begin{abstract}
Abstrak: Karies gigi dapat diatasi dengan restorasi menggunakan resin komposit yang banyak digunakan sebagai bahan restorasi gigi anterior karena memiliki keunggulan estetik yaitu menyerupai warna gigi. Dokter gigi wajib memenuhi harapan pasien dengan pelayanan sebaik mungkin. Untuk mengetahui kepuasan pasien terhadap hasil restorasi, dapat dilihat dari penilaian pasien. Tujuan penelitian ini yaitu untuk mengetahui tingkat kepuasan pasien terhadap perawatan tumpatan komposit pada gigi anterior di RSGM Unsrat. Jenis penelitian ialah deskriptif dengan desain potong lintang. Responden penelitian ialah pasien yang dipilih dengan metode purposive sampling sebanyak 30 orang. Instrumen penelitian yang digunakan yaitu kuesioner dengan pertanyaan tertutup. Data diolah secara deskriptif kemudian disajikan berdasarkan distribusi dalam bentuk grafik. Hasil penelitian menunjukkan bahwa tingkat kepuasan responden terhadap hasil tumpatan paling banyak ialah sangat puas $(45 \%)$ dan yang paling sedikit yaitu kurang puas (2\%). Tingkat kepuasan responden terhadap warna bahan tumpatan komposit paling banyak ialah cukup puas (33\%). Tingkat kepuasan responden terhadap ukuran gigi setelah ditumpat paling banyak ialah puas (76\%). Simpulan penelitian ini ialah kepuasan responden terhadap perawatan tumpatan komposit pada gigi anterior yang paling dominan pada kategori puas tentang ukuran gigi setelah ditumpat dan pada kategori cukup puas tentang warna bahan tumpatan.
\end{abstract}

Kata kunci: tumpatan komposit, gigi anterior, kepuasan pasien 
Hasil Riset Kesehatan Dasar (Riskesdas) pada tahun 2018, menunjukkan bahwa prevalensi penduduk yang memiliki masalah kesehatan gigi dan mulut sebanyak $57,6 \%$ dan terdapat 21 provinsi yang mempunyai prevalensi masalah gigi dan mulut di atas angka nasional. Karies gigi masih merupakan masalah di antara penyakit gigi dan mulut lainnya, sedangkan di Provinsi Sulawesi Utara dilaporkan tingkat kejadian karies gigi sebesar 55,5\%. ${ }^{1}$ Salah satu cara mengatasi karies gigi yaitu dengan melakukan penumpatan.

Resin komposit merupakan salah satu jenis bahan tumpatan yang memiliki keunggulan dalam bidang estetik karena memiliki karakteristik warna yang menyerupai gigi asli. Sesuai dengan perkembangan ilmu kedokteran gigi konservatif, resin komposit mulai banyak digunakan sebagai bahan restorasi gigi anterior karena permintaan pasien yang menginginkan restorasi sewarna gigi. ${ }^{2}$ Suatu tindakan restorasi gigi tidak hanya meliputi pembuangan karies kemudian memperbaiki fungsi gigi tersebut, tetapi juga bertujuan untuk mencegah terjadinya karies kembali, serta kebutuhan pasien untuk mendapatkan hasil perawatan gigi yang memenuhi syarat estetik menjadi pertimbangan dalam pemilihan bahan restorasi. ${ }^{3}$

Hasil perawatan harus sejalan dengan harapan pasien yaitu menampilkan estetik gigi yang lebih baik. Setiap orang memiliki persepsi yang berbeda terhadap perawatan yang diterima, sehingga menjadi kewajiban dokter gigi untuk memenuhi harapan pasien dengan pelayanan sebaik mungkin. Untuk mengetahui kepuasan pasien terhadap hasil tindakan restorasi terutama ditentukan dari penilaian estetik oleh pasien. Hal ini tentunya sangat tergantung pada kualitas bahan yang akan digunakan, teknik preparasi dan penumpatan oleh dokter gigi yang bersangkutan. ${ }^{4}$ Tingkat kepuasan pasien penting diketahui untuk terus meningkatkan pelayanan konservatif dengan bahan resin komposit. Kepuasan pasien menjadi salah satu acuan keberhasilan perawatan tumpatan komposit.

Penggunaan bahan tumpatan resin komposit merupakan salah satu pilihan yang digunakan dalam perawatan tumpatan komposit pada gigi anterior di Rumah Sakit Gigi dan Mulut Universitas Sam Ratulangi (RSGM Unsrat). Survei awal yang dilakukan oleh penulis menunjukkan terdapat 455 kasus tumpatan komposit. ${ }^{5}$ Peneitian yang dilakukan di RSGM Unsrat pada tahun 2012 menunjukkan 54,1\% tumpatan komposit dilakukan pada gigi anterior. ${ }^{6}$ Sampai saat ini belum pernah dilaporkan penelitian yang dilakukan di RSGM Unsrat untuk melihat tingkat kepuasan pasien terhadap pelayanan yang telah diberikan. Berlatar belakang hal tersebut maka penulis melakukan penelitian mengenai tingkat kepuasan pasien terhadap perawatan tumpatan komposit pada gigi anterior di RSGM Unsrat.

\section{METODE PENELITIAN}

Penelitian ini dilaksanakan di RSGM Unsrat, Jl. Dr. Sutomo, Kecamatan Wenang, Kota Manado, Provinsi Sulawesi Utara pada bulan Mei 2019. Jenis penelitian ialah deskriptif dengan desain potong lintang. Populasi penelitian ini yaitu semua pasien yang menerima perawatan tumpatan komposit pada gigi anterior dan sudah selesai tahap kontrol di RSGM Unsrat pada periode bulan Maret 2018-Maret 2019 dengan jumlah 79 orang. Teknik pengambilan sampel yang digunakan ialah metode purposive sampling, dengan besar sampel 30 diambil berdasarkan kriteria inklusi dan eksklusi.

\section{HASIL PENELITIAN}

Penelitian ini dilakukan dengan melihat rekam medik pasien yang melakukan perawatan tumpatan komposit pada gigi anterior pada periode Maret 2018-2019. Setelah dijabarkan dalam kriteria inklusi didapatkan responden penelitian berjumlah 30 orang, terdiri dari 24 orang laki-laki $(80 \%)$ dan 6 orang perempuan $(20 \%)$.

Gambar 1 memperlihatkan distribusi karakteristik berdasarkan usia, dan responden terbanyak berada pada rentang usia 2130 tahun $(43,3 \%)$. 


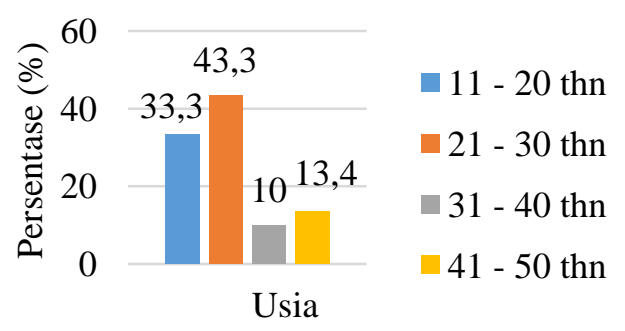

Gambar 1. Distribusi karakteristik responden berdasarkan usia

Gambar 2 menunjukkan bahwa responden paling banyak yang berusia 21 sampai 30 tahun berjumlah 13 orang $(43,3 \%)$, sedangkan yang paling sedikit yaitu yang berusia 31 sampai 40 tahun berjumlah 3 orang (10\%).

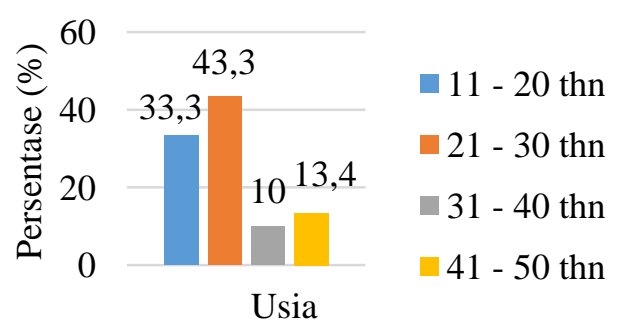

Gambar 2. Distribusi karakteristik responden berdasarkan usia

Gambar 3 menunjukkan bahwa responden paling banyak bekerja sebagai pelajar/ mahasiswa yaitu berjumlah 13 orang $(43,3 \%)$, sedangkan yang paling sedikit bekerja sebagai pelajar, wirausaha dan ASN serta memiliki jumlah yang sama sebanyak 2 orang $(6,7 \%)$.

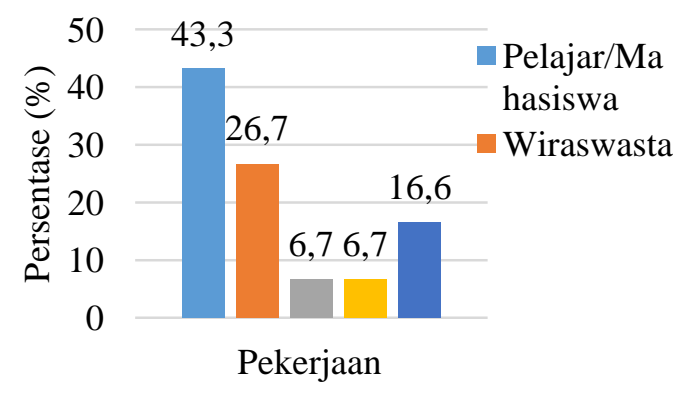

Gambar 3. Distribusi karakteristik responden berdasarkan jenis pekerjaan.

Gambar 4 menunjukkan bahwa tingkat pendidikan responden paling banyak yaitu
SMA sebanyak 18 orang $(60 \%)$ dan yang paling sedikit tingkat SMP sebanyak 3 orang $(10 \%)$.

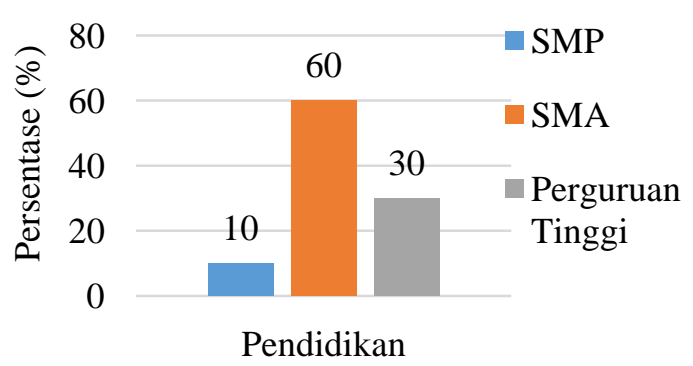

Gambar 4. Distribusi karakteristik responden berdasarkan tingkat pendidikan.

Gambar 5 menunjukkan responden dengan gigi yang paling banyak ditumpat yaitu gigi insisivus sentral kiri atas sebanyak 9 orang (30\%), sedangkan yang paling sedikit yaitu gigi insisivus lateral kanan atas, kaninus kanan atas dan insisivus lateral kanan bawah dengan jumlah yang sama sebanyak 1 orang $(3,3 \%)$.

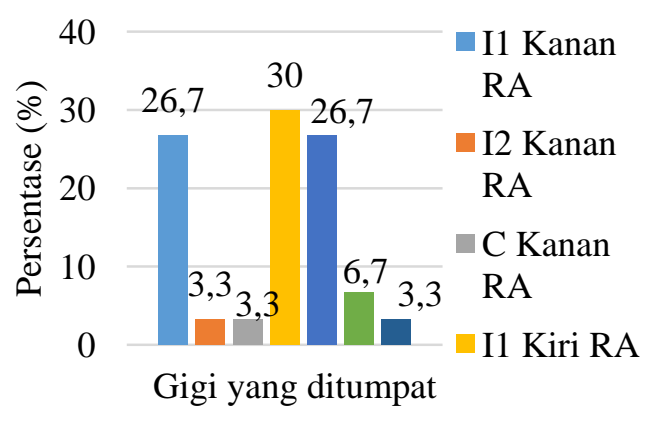

Gambar 5. Distribusi karakteristik responden berdasarkan gigi yang ditumpat

Gambar 6 menunjukkan bahwa tingkat kepuasan responden terhadap hasil tumpatan paling banyak ialah 11 orang memilih jawaban sangat puas dengan skor $55(45 \%)$ dan yang paling sedikit yaitu 1 orang memilih jawaban kurang puas dengan skor $2(2 \%)$.

Gambar 7 menunjukkan bahwa tingkat kepuasan responden terhadap perubahan penampilan gigi setelah ditambal paling banyak ialah 17 orang yang memilih jawaban puas dengan skor $68(58 \%)$ dan yang paling sedikit yaitu 2 orang memilih 
jawaban kurang puas dengan skor 4 (3\%).

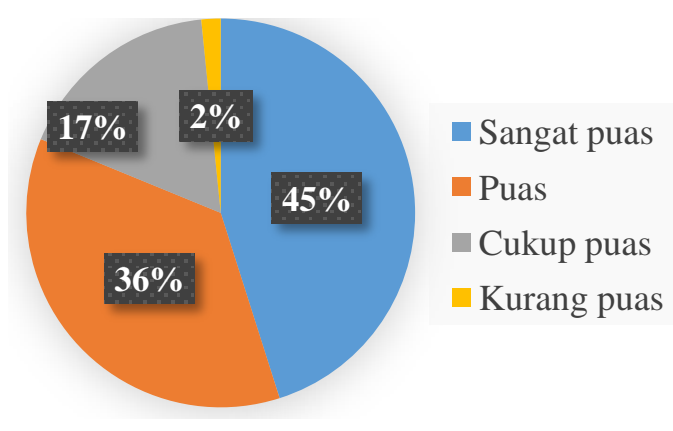

Gambar 6. Distribusi kepuasan responden terhadap hasil tumpatan

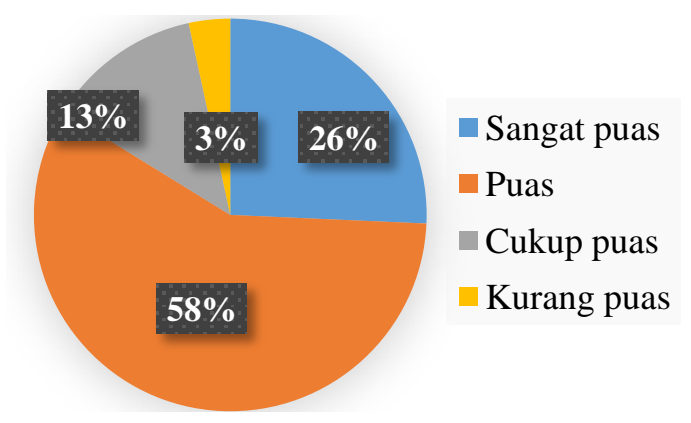

Gambar 7. Distribusi kepuasan responden terhadap perubahan penampilan gigi setelah ditumpat

Gambar 8 menunjukkan bahwa tingkat kepuasan responden terhadap penampilan gigi saat tersenyum paling banyak ialah 19 orang yang memilih jawaban puas dengan skor $76(66 \%)$ dan jawaban kurang puas yang paling sedikit dipilih oleh 2 orang dengan skor $4(4 \%)$.

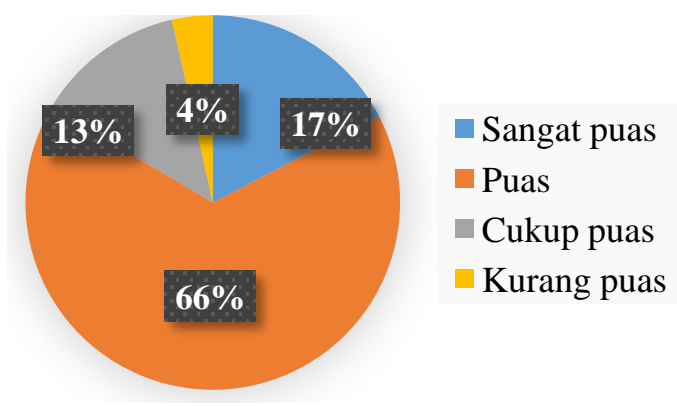

Gambar 8. Distribusi kepuasan responden terhadap penampilan gigi saat tersenyum

Gambar 9 menunjukkan bahwa tingkat kepuasan responden terhadap warna bahan tumpatan yang digunakan yaitu komposit paling banyak ialah 12 orang yang memilih jawaban cukup puas dengan skor 36 (33\%) dan paling sedikit jawaban kurang puas dipiih oleh 2 orang dengan skor 4 (4\%).

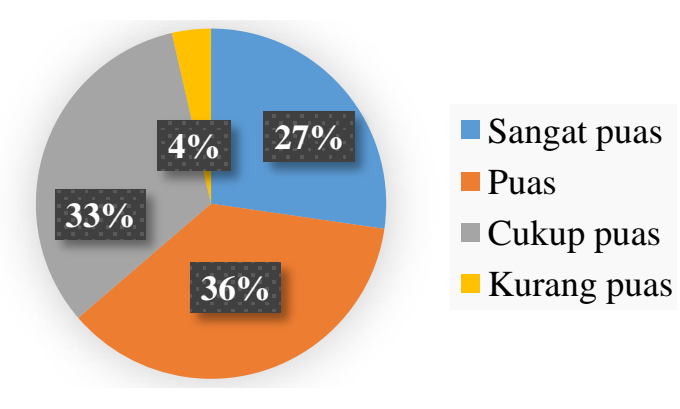

Gambar 9. Distribusi kepuasan responden terhadap warna bahan tumpatan

Gambar 10 menunjukkan bahwa berdasarkan tingkat kepuasan responden terhadap ukuran gigi setelah ditumpat paling banyak ialah 22 orang memilih jawaban puas dengan skor $88(76 \%)$ dan paling sedikit ialah pilihan jawaban kurang puas oleh 2 orang dengan skor 4 (3\%).

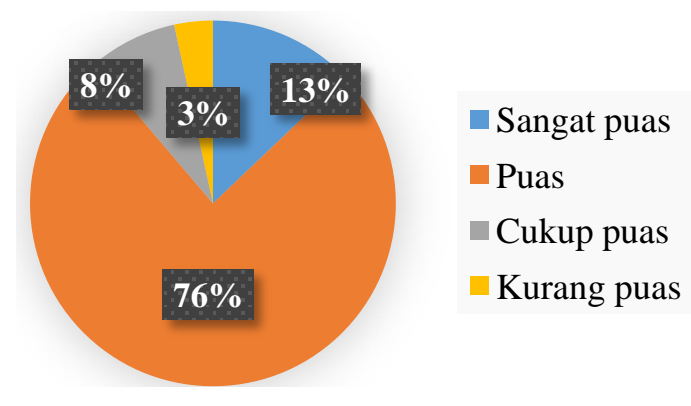

Gambar 10. Distribusi kepuasan responden terhadap ukuran gigi setelah ditumpat

Gambar 11 menunjukkan bahwa hasil yang didapat berdasarkan tingkat kepuasan responden terhadap bentuk gigi setelah ditumpat, paling banyak jawaban puas dipilih oleh 18 orang dengan skor 72 (65\%), sebanyak 1 orang memilih jawaban sangat tidak puas dengan skor $1(1 \%)$.

Gambar 12 menunjukkan bahwa tingkat kepuasan responden terhadap susunan gigi setelah ditumpat paling banyak dengan jawaban puas yaitu sebanyak 15 orang dengan skor 60 (55\%), yang paling sedikit yaitu jawaban kurang puas sebanyak 1 orang dengan skor $2(2 \%)$. 


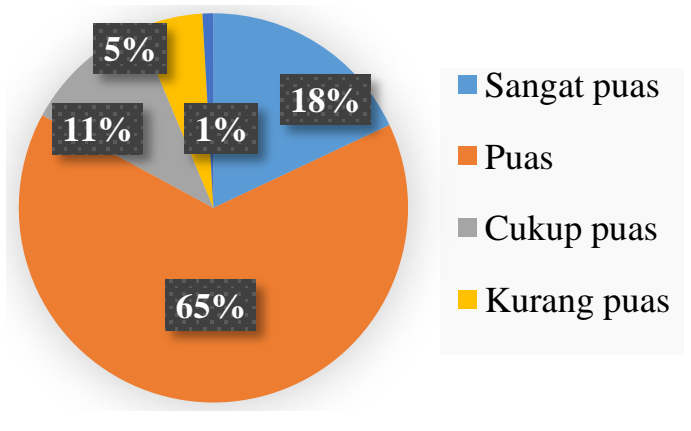

Gambar 11. Distribusi kepuasan responden terhadap bentuk gigi setelah ditumpat

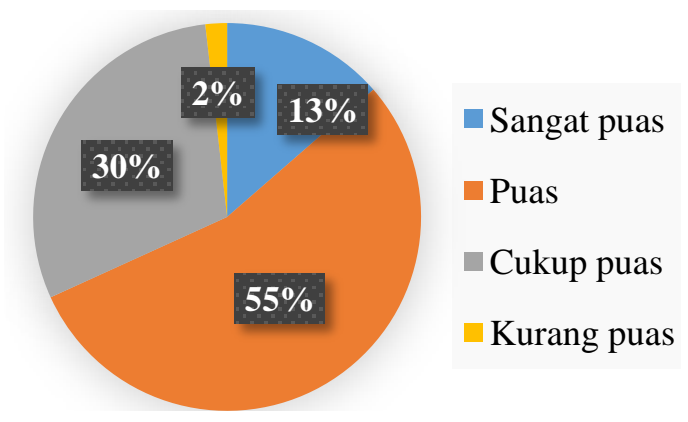

Gambar 12. Distribusi kepuasan responden terhadap susunan gigi setelah ditumpat

Gambar 13 menunjukkan bahwa tingkat kepuasan responden terhadap kesejajaran gigi setelah ditumpat yang paling banyak yaitu 14 orang memilih jawaban puas dengan skor $56(49 \%)$ dan paling sedikit ialah 3 orang memilih jawaban kurang puas dengan skor $6(5 \%)$.

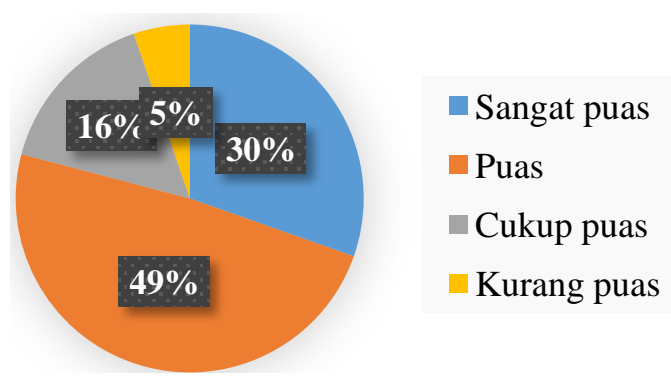

Gambar 13. Distribusi kepuasan responden terhadap kesejajaran gigi setelah ditumpat

Gambar 14, menunjukkan bahwa hasil yang didapat berdasarkan tingkat kepuasan responden terhadap gigi yang ditumpat saat digunakan mengunyah paling banyak ialah 13 orang memilih jawaban puas dengan skor $52(49 \%)$ dan yang paling sedikit yaitu
1 orang memilih jawaban sangat tidak puas dengan skor $1(1 \%)$.

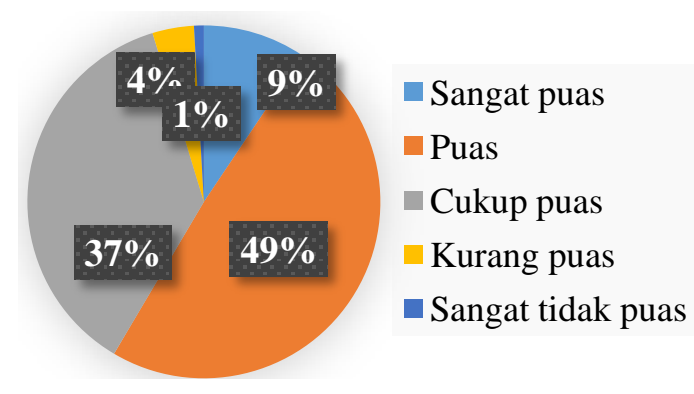

Gambar 14. Distribusi kepuasan responden terhadap gigi yang ditumpat saat digunakan mengunyah

Gambar 15 menunjukkan bahwa tingkat kepuasan responden terhadap pelayanan yang diberikan operator pada saat perawatan paling banyak memilih jawaban sangat puas yaitu sebanyak 16 orang dengan skor 80 (59\%), dan yang paling sedikit 1 orang memilih cukup puas dengan skor 3 (2\%).

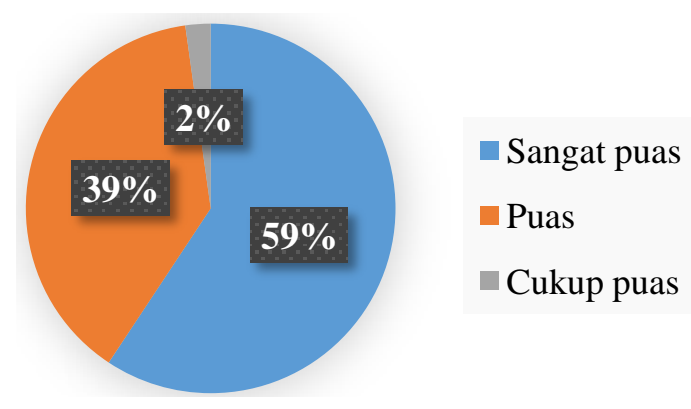

Gambar 15. Distribusi kepuasan responden terhadap pelayanan yang diberikan operator saat perawatan

\section{BAHASAN}

Hasil penelitian ini menunjukkan bahwa perempuan merupakan responden terbanyak yang melakukan perawatan tumpatan komposit pada gigi anterior yaitu sebanyak $80 \%$ dibandingkan laki-laki sebanyak $20 \%$. Hasil penelitian yang sama mengenai gambaran penggunaan bahan tumpatan komposit juga pernah dilakukan di RSGM Unsrat, dimana pasien perempuan $(55,6 \%)$ merupakan pasien yang paling sering melakukan perawatan tumpatan komposit dibandingkan laki-laki $(44,4 \%) .^{7} \quad$ Penelitian yang dilakukan 
Ananda $^{8}$ tentang frekuensi penggunaan tumpatan komposit juga menunjukkan hal yang sama yaitu perempuan $(70,1 \%)$ lebih banyak daripada laki-laki $(29,9 \%) .{ }^{8}$ Bagi kaum perempuan, penampilan gigi merupakan hal yang penting karena juga merupakan bagian dari penampilan wajah. Gigi yang memenuhi syarat estetik terlebih pada gigi anterior sangat menunjang penampilan dan meningkatkan rasa kepercayaan diri perempuan sedangkan pada laki-laki hanya sebagian kecil yang memperhatikan hal tersebut dan yang paling diharapkan hanyalah dapat mengembalikan fungsi gigi tersebut. ${ }^{9}$ Hal ini sejalan dengan hasil penelitian yang dilakukan di Fakultas Kedokteran Universitas Udayana pada tahun 2017 bahwa 79,9\% responden perempuan tidak puas dengan estetik gigi dan pada laki-laki hanya $23,1 \% .^{10}$

Berdasarkan Gambar 2, karakteristik responden menurut usia menunjukkan bahwa responden yang terbanyak pada kelompok usia 21-30 tahun yaitu sebesar $43,3 \%$, sedangkan pada kelompok usia 3140 tahun sebanyak $13,4 \%$ yaitu masuk kategori terendah atau yang paling sedikit melakukan tumpatan komposit pada gigi anterior. Hal ini menunjukkan bahwa di usia muda lebih tinggi tingkat kesadaran untuk memelihara kesehatan gigi dan berusaha mempertahankan gigi dalam mulut. Hasil penelitian ini juga menemukan hasil yang sama dengan penelitian yang dilakukan di RSGM Unsrat tahun 2014 dimana subjek terbanyak 21-30 tahun yaitu sebanyak 70\%. ${ }^{11}$ Penelitian lain yang dilakukan oleh Satiti di RSGM Universitas Jember menunjukkan subjek terbanyak yaitu pada usia 21-26 tahun dengan persentase $50,5 \% .^{12}$ Pada kelompok usia 21-30 tahun kebanyakan sudah menyadari keadaan gigi dan mengetahui pentingnya merawat gigi serta sangat peduli terhadap estetik gigi untuk menunjang penampilan mereka. ${ }^{13}$ Kelompok usia 31-40 tahun cenderung kurang memperhatikan kesehatan gigi dan mulut, meskipun sadar adanya karies tetapi mereka justru mengabaikannya. ${ }^{14}$

Berdasarkan Gambar 3, karakteristik responden menurut jenis pekerjaan, dalam penelitian ini menunjukkan bahwa kelompok yang paling banyak mendapatkan perawatan tumpatan komposit pada gigi anterior ialah pelajar/mahasiswa yaitu sebanyak 43,3\%. Sejalan dengan penelitian yang dilakukan di Poliklinik Gigi RUMKITAL dr. Wahyu Slamet, subjek terbanyak yaitu dengan pekerjaan sebagai pelajar. Hal ini bisa saja disebabkan karena sebagian besar pelajar/mahasiswa belum memiliki penghasilan sendiri dan memiliki kebutuhan yang lebih banyak, sehingga mahasiswa mencari tempat perawatan gigi dengan harga yang cukup terjangkau agar giginya bisa dirawat. ${ }^{10}$

Berdasarkan Gambar 4, karakteristik responden menurut tingkat pendidikan, pasien dengan pendidikan sampai SMA (60\%) yang paling banyak melakukan perawatan tumpatan komposit pada gigi anterior. Pada tingkat pendidikan SMA rata-rata pengetahuan pasien akan pentingnya kesehatan gigi dan mulut serta cara untuk menangani ketika adanya kerusakan gigi seperti karies sudah cukup baik. Dengan demikian mereka juga lebih mengetahui cara penanganan karies dengan melakukan perawatan tumpatan komposit. $^{15}$

Berdasarkan Gambar 5, karakteristik responden meurut gigi yang ditumpat, pada penelitian ini menunjukkan bahwa gigi insisivus sentral kiri atas merupakan gigi yang paling banyak dilakukan tumpatan yaitu sebanyak 30\%. Hal ini bisa disebabkan karena gigi insisivus sentral paling rentan mengalami fraktur atau trauma, kebiasaan buruk seperti menggigit pulpen menyebabkan gigi patah, selain itu bisa juga karena atrisi, abrasi serta adanya karies gigi karena kurang menjaga kebersihan gigi. Hal ini sesuai dengan fungsi gigi insisivus sebagai pemotong makanan. Karies sekunder juga bisa menjadi faktor penunjang seseorang ingin ditumpat giginya. Salah satu penyebabnya yaitu kegagalan dalam penumpatan sebelumnya. ${ }^{16}$ Diagnosis yang tepat serta akurat pada karies dini sangat membantu dalam menetapkan rencana perawatan dan dapat 
mencegah kerusakan yang tidak perlu karena kesalahan operator. ${ }^{2}$

Hasil penelitian ini mendapatkan menurut penilaian terbanyak oleh responden yaitu tentang hasil tumpatan secara keseluruhan ialah $45 \%$, perubahan penampilan gigi setelah ditumpat $58 \%$, penampilan gigi saat tersenyum $66 \%$, warna bahan tumpatan $36 \%$, ukuran gigi setelah ditumpat $76 \%$, bentuk gigi setelah ditumpat $65 \%$, susunan gigi setelah ditumpat $55 \%$, kesejajaran gigi setelah ditumpat $49 \%$, fungsional gigi yang ditumpat saat digunakan mengunyah serta penilaian terhadap pelayanan yang diberikan operator saat perawatan $59 \%$.

Penilaian responden dalam penelitian ini bisa saja dipengaruhi oleh faktor selama manipulasi komposit atau setelah manipulasi yaitu saat digunakan dalam rongga mulut. Hasil tumpatan komposit yang diharapkan oleh responden adalah tetap baik untuk jangka waktu yang cukup lama setelah ditumpat. Penelitian menunjukkan bahwa daya tahan tumpatan resin komposit hanya berkisar 5-10 tahun dan setelah itu perlu diganti. ${ }^{16}$

Warna bahan tumpatan memiliki peran besar yang bisa memengaruhi tingkat kepuasan pasien. Gambar 9 menunjukkan bahwa warna bahan tumpatan gigi memperoleh nilai yang rendah yaitu $32,7 \%$ atau masuk dalam kategori kurang puas. Hal ini bisa saja terjadi karena warna bahan tumpatan komposit yang digunakan oleh operator tidak sesuai dengan warna gigi pasien. ${ }^{2}$ Faktor lainnya yang juga bisa berpotensi memengaruhi penilaian yaitu perubahan warna komposit setelah sekian lama ditumpat. ${ }^{16}$ Penelitian yang dilakukan pada tahun 2013 juga menunjukkan distribusi kerusakan gigi pasca restorasi komposit termasuk perubahan warna mencapai $7 \% .^{3}$ Sharma $^{17}$ menyatakan bahwa warna gigi merupakan salah satu faktor yang memengaruhi estetik dan memiliki peran besar dari penilaian ketidakpuasan terhadap penampilan estetik gigi seseorang. Warna gigi memiliki korelasi yang kuat dengan usia fisiologis seseorang, umumnya menjadi lebih gelap dan lebih kuning seiring dengan pertam-bahan usia. ${ }^{17}$ Teknik penumpatan yang digunakan juga bisa memengaruhi perubahan warna tepi tumpatan. Hasil penelitian yang dilakukan oleh Sima et $\mathrm{al}^{18}$ menyatakan bahwa terdapat perbedaan bermakna perubahan warna marginal resin komposit dengan beberapa teknik penumpatan. Hasil penelitian ini menunjuk-kan bahwa teknik penumpatan secara inkremental dan pengaplikasian teknik re-etch re-bond setelah finishing dapat meminimalkan terjadinya perubahan warna tepi tumpatan. ${ }^{18}$

Berdasarkan Gambar 10, penelitian ini menunjukkan bahwa penilaian terbanyak tentang ukuran gigi yaitu $75,9 \%$ artinya responden menyatakan puas untuk ukuran gigi setelah ditumpat. Ukuran gigi tidak hanya relevan dengan estetik gigi tetapi juga dengan estetik wajah. Ukuran gigi harus proporsional dengan gigi lainnya dan wajah. Penampilan ukuran gigi sebelum ditumpat biasanya menjadi patokan penilaian pasien. Untuk masalah gigi seperti gigi patah, atrisi, abrasi atau karies gigi yang cukup parah akan sangat memengaruhi penilaian pasien terhadap ukuran gigi setelah ditumpat. Biasanya pasien dengan kasus tersebut sangat memperhatikan penampilan ukuran gigi mereka. ${ }^{19}$

Berdasarkan Gambar 12 dan Gambar 13, penelitian ini menunjukkan rerata penilaian pasien mengenai susunan gigi $(54,6 \%)$ dan kesejajaran gigi $(48,7 \%)$ yang ditumpat masih pada kategori penilaian cukup puas. Perawatan tumpatan komposit pada gigi anterior adalah perawatan yang juga mementingkan penampilan estetik yang baik. Susunan gigi penting untuk melihat keseimbangan antara gigi yang ditumpat dengan gigi lainnya, serta bermanfaat untuk mencegah terjadinya prematur kontak pada gigi yang ditumpat, terlebih jika adanya maloklusi. Kesejajaran gigi juga penting karena berhubungan dengan penampilan estetik. Faktor-faktor yang memengaruhi kesejajaran gigi ialah posisi gigi, simetri tidaknya gigi geligi serta hubungan mid-line gigi dengan mid-line wajah dan bibir. Posisi gigi yang teratur dan berada pada satu lengkung rahang 
dengan oklusi yang baik, akan menunjang penampilan estetik gigi yang ditumpat. ${ }^{19}$ Pada penelitian yang dilakukan oleh Wijaya, menyatakan bahwa terdapat hubungan antara ukuran wajah dengan ukuran lengkung gigi rahang atas, hal ini menunjukkan pentingnya memperhatikan ukuran wajah dengan ukuran lengkung gigi saat melakukan perawatan. ${ }^{20}$

Berdasarkan grafik 14, kepuasan pasien mengenai gigi yang ditumpat saat digunakan mengunyah juga masih memperoleh penilaian cukup puas $(49,1 \%)$. Hal ini bisa saja karena pasien merasa tidak nyaman dengan giginya saat digunakan mengunyah. Kemungkinan karena pengaplikasian tumpatan yang kurang baik dan memengaruhi susunan gigi, kemudian menyebabkan terjadinya prematur kontak gigi yang ditumpat sehingga tidak nyaman ketika digunakan mengunyah. ${ }^{2}$ Untuk mengatasi hal ini operator harus lebih teliti saat pengaplikasian bahan tumpatan komposit.

Berdasarkan grafik 11, hasil penilaian kepuasan pasien berdasarkan bentuk gigi menunjukkan bahwa rata-rata responden menyatakan puas $(64,9 \%)$. Bentuk gigi dapat diklasifikasikan dalam 3 bentuk yaitu persegi panjang, segitiga dan lonjong (oval). Biasanya bentuk gigi yang lebih disukai apabila bentuk kedua insisivus pertama rahang atas identik dengan bentuk wajah. ${ }^{19}$ Selain itu memperhatikan jenis kelamin juga penting, karena pada perempuan biasanya ditandai dengan sudut yang membulat sedangkan pada pria dengan sudut yang lebih persegi. Bentuk gigi perempuan biasanya lebih kecil dari bentuk gigi laki-laki. Bentuk gigi setelah ditumpat yang memuaskan ialah semaksimal mungkin proporsional dengan bentuk gigi sebelahnya atau sebisa mungkin seperti bentuk asli.

Berdasarkan grafik 15, penilaian terbanyak tentang pelayanan yang diberikan operator pada saat perawatan yaitu 59,3\% atau masuk pada kategori cukup puas. Kepuasan pasien mengenai pelayanan operator bisa dipengaruhi oleh beberapa hal seperti keterampilan, keramahan, dan kecepatan pelayanan. $^{21}$ Keterampilan operator merupakan poin penting pada saat melakukan perawatan. Dimulai dari tahap preparasi sampai penumpatan serta finishing dan polishing, termasuk pada penilaian keterampilan operator. $^{2}$ Hasil akhir akan dilihat dan dinilai oleh pasien. Tumpatan yang baik dapat memberikan kepuasan kepada pasien. Keramahan operator dan kecepatan pelayanan yang diberikan operator juga memengaruhi penilaian kepuasan pasien. Kecepatan pelayanan berhubungan dengan lama waktu kerja operator. Pada penelitian ini pasien merasa cukup puas, hal ini bisa juga disebabkan karena waktu pengerjaan yang terlalu lama. ${ }^{21}$

Pada dasarnya, tingkat kepuasan pasien atas kualitas perawatan di suatu instansi berpengaruh pada pola perilaku selanjutnya. Apabila pasien merasa puas, maka pasien akan menunjukkan besarnya kemungkinan untuk kembali datang berkunjung ke tempat perawatan sebelumnya. $^{21}$ Oleh karena itu penting untuk mengetahui kepuasan pasien terhadap perawatan tumpatan komposit pada gigi anterior untuk meningkatkan kualitas pelayanan.

\section{SIMPULAN}

Berdasarkan hasil penelitian ini dapat disimpulkan bahwa kepuasan responden terhadap perawatan tumpatan komposit pada gigi anterior yang paling dominan pada kategori puas tentang ukuran gigi setelah ditumpat dan yang paling rendah pada kategori kurang puas yaitu warna bahan tumpatan.

Bagi dokter gigi disarankan untuk meningkatkan kualitas pelayanan serta kualitas dan jenis bahan yang digunakan pada tumpatan komposit di gigi anterior. Perlu dilakukan penelitian lebih lanjut mengenai tingkat kepuasan pasien terhadap perawatan tumpatan komposit pada gigi anterior di rumah sakit gigi mulut lainnya sebagai data pembanding terhadap hasil penelitian ini. 
DAFTAR PUSTAKA

1. Balitbang. Riset Kesehatan Dasar: Riskesdas 2018. Jakarta: Balitbang Kemenkes RI, 2018; p. 181,185, 204.

2. Adhidarma T, Untara TE, Iskandar B. Restorasi estetik resin komposit dengan color modifier pada gigi insisivus sentralis maksila hipoplasia enamel kavitas kelas IV. MIKGI 2011: 61-7.

3. Tambahani AM, Wicaksono DA, Tumewu E. Gambaran kerusakan gigi pasca restorasi komposit pada siswa SMA Negeri 1 Manado. eG. 2013; 1(2):1247.

4. Mukuan T, Abidjulu J, Wicaksono DA. Gambaran kebocoran tepi tumpatan pasca restorasi resin komposit pada mahasiswa Program Studi Kedokteran Gigi Angkatan 2005-2007. eG. 2013; 1(2):116-8.

5. Tangki MF. Rekapitulasi jumlah tindakan pasien. Laporan Akhir. Manado: RSGM Unsrat, 2018; p. 3.

6. Sajow P, Rattu AJM, Wicaksono DA. Gambaran penggunaan bahan restorasi resin komposit di Balai Pengobatan Rumah Sakit Gigi dan Mulut Universitas Sam Ratulangi Tahun 2011-2012. eG. 2013;1(2):7.

7. Wigati PR, Pangemanan DHC, Parengkuan WG. Gambaran penggunaan bahan tumpatan di Rumah Sakit Gigi dan Mulut PSPDG Fakultas Kedokteran Unsrat Tahun 2015. eG. 2015;5(2):46.

8. Ananda L. Frekuensi penggunaan GIC dan resin komposit sebagai tumpatan gigi tetap di Puskesmas Jeulingke Kota Banda Aceh Tahun 2014 [Electronic Theses and Dissertasions]. Banda Aceh: Universitas Syah Kuala; 2015.

9. Da Silva GdC, de Castilhos ED, Masotti AS, Rodrigues AS. Dental Esthetic SelfPerception of Brazilian Dental Students. Original Research Article RSBO. 20129(4): 380.

10. Tulenan DMP, Wicaksono DA, Soewantoro JS. Gambaran Tumpatan Resin Komposit Pada Gigi Permanen Di Poliklinik Gigi RUMKITAL dr. Wahyu Slamet. eG. 2014;2(2):3.

11. Anang DY, Mariati NW, Mintjelungan CN. Penggunaan bahan tumpatan di Rumah Sakit Gigi dan Mulut PSPDG Fakultas Kedokteran Unsrat Pada
Tahun 2014. eG. 2014;3(2):258.

12. Satiti I, Fatmawati DWA, Lestari S. Prevalensi indikasi perawatan tumpatan pada pasien yang berkunjung ke RSGM Universitas Jember Tahun 2015. E-Jurnal Pustaka Kesehatan. 2017;5(1):130.

13. Wulandari, I Gst AA, Dewi K, Ratna P, Adijanti G. Persepsi mahasiswa PSPDG Fakultas Kedokteran Universitas Udayana terhadap senyum dan estetika gigi. Bali Dental Journal. 2017;1(1): 23-7.

14. Surentu GF. Gambaran penggunaan bahan tumpatan resin komposit di Poli Gigi RS Advent Manado pada tahun 2010 Sampai Tahun 2011 [Skripsi]. Manado: Universitas Sam Ratulangi; 2012.

15. Yohanes IGK, Pandelaki K, Mariati NW. Hubungan Pengetahuan kebersihan gigi dan mulut dengan status kebersihan gigi dan mulut pada siswa SMA Negeri 9 Manado. eG. 2013;1(2):86-7.

16. Gulamali AB, Hemmings KW, Tredwin CJ, Petrie A. Survival analysis of composite Dahl restorations provided to manage localised anterior tooth wear (Ten year follow up). British Dental Journal. 2011;211(9):3-5.

17. Sharma V. A study of relationship between skin colour and tooth shade value in population of Udaipur, Rajasthan. Int $\mathbf{J}$ Dent Clinics. 2010;2(4):26-8.

18. Sima ND, Sutrisno G, Asrianti D. Perbedaan perubahan warna marginal pada resin komposit nanohybrid pada beberapa teknik penumpatan setelah perendaman kopi. Jakarta: FKG UI. 2013 p. 379-380.

19. Goldstein RE, DDS, Patzer G. Concepts of Dental Esthetics (3rd ed). Hoboken, New Jersey: John Wiley \& Sons Inc. , 2018; p. 6,10.

20. Wijaya SB. Hubungan ukuran dan bentuk wajah dengan ukuran dan bentuk lengkung gigi rahang atas [Electronic Theses and Dissertasion].Yogyakarta: Universitas Gajah Mada; 2015.

21. Nurhaeni HJ, Abdullah N. Tingkat kepuasan pasien terhadap pelayanan kesehatan gigi dan mulut di Puskesmas Bangkala Kabupaten Jeneponto. Media Kesehatan Gigi. 2018;17(2):20-6. 